\title{
Associations of plasma IGF1, IGFBP3 and estradiol with leucocyte telomere length, a marker of biological age, in men
}

\section{Bu B Yeap ${ }^{1,2}$, Jennie Hui ${ }^{3}$, Matthew W Knuiman4, S A Paul Chubb ${ }^{1,5}$, Ken K Y Ho ${ }^{6}$, Leon Flicker ${ }^{1,7}$, Mark L Divitini ${ }^{4}$, Gillian M Arscott ${ }^{3}$, Stephen M Twigg ${ }^{8}$, Osvaldo P Almeida ${ }^{1,7}$, Graeme J Hankey ${ }^{1}$, Jonathan Golledge ${ }^{9}$ and John P Beilby}

${ }^{1}$ Medical School, University of Western Australia, Perth, Western Australia, Australia, ${ }^{2}$ Department of Endocrinology and Diabetes, Fiona Stanley Hospital, Perth, Western Australia, Australia, ${ }^{3}$ PathWest Laboratory Medicine, Sir Charles Gairdner Hospital, Perth, Western Australia, Australia, ${ }^{4}$ School of Population and Global Health, University of Western Australia, Perth, Western Australia, Australia, ${ }^{5}$ PathWest Laboratory Medicine, Fiona Stanley Hospital, Perth, Western Australia, Australia, ${ }^{6} \mathrm{Garvan}$ Institute of Medical Research and St Vincent's Hospital, Sydney, New South Wales, Australia, ${ }^{7}$ WA Centre for Health \& Ageing, University of Western Australia, Perth, Western Australia, Australia, ${ }^{8}$ Department of Endocrinology, Sydney Medical School, University of Sydney, Sydney, New South Wales, Australia, and ${ }^{9}$ Queensland Research Centre for Peripheral Vascular Disease, James Cook University and Department of Vascular and Endovascular Surgery, Townsville Hospital, Townsville, Queensland, Australia

Correspondence should be addressed to B B Yeap Email

bu.yeap@uwa.edu.au

\begin{abstract}
Objective: Effects of insulin-like growth factor 1 (IGF1) and its binding proteins (IGFBPs) on ageing, and their interaction with sex hormones, remain uncertain. We examined associations of plasma IGF1, IGFBP1, IGFBP3, estradiol and testosterone, with leucocyte telomere length (LTL), a marker of biological age, in 2999 community-dwelling men aged 70-84 years.

Methods: Plasma IGF1, IGFBP1 and IGFBP3 measured using immunoassay, sex hormones using mass spectrometry. LTL measured by PCR, expressed as ratio of telomeric to single-copy control gene DNA (T/S ratio). Linear regression models adjusted for age and cardio-metabolic risk factors, median splits defined low/high groups.

Results: Mean age was $76.7 \pm 3.2$ years. IGF1 and IGFBP3 showed age-adjusted correlations with LTL (coefficient 0.59, $P=0.001$ and $0.45, P=0.013$ respectively), IGFBP1 did not. In multivariable-adjusted models IGF1 and IGFBP3 (but not IGFBP1) were associated with LTL (T/S ratio 0.015 higher per 1 s.D. increase in IGF1, $P=0.007$, and 0.011 per 1 s.D. IGFBP3, $P=0.049$ ). IGF1 and estradiol were independently associated with longer telomeres (T/S ratio 0.012 higher per 1 S.D. increase in estradiol, $P=0.027$, when included in model with IGF1). Testosterone was not associated with LTL. Men with both high IGF1 (>133 $\mathrm{gg} / \mathrm{L}$ ) and high estradiol (>70 pmol/L) had longer LTL compared to men with lower values (multivariable-adjusted T/S ratio 1.20 vs $1.16, P=0.018$ ).

Conclusions: Higher IGF1 and IGFBP3 are independently associated with longer telomeres in older men. Additive associations of higher IGF1 and higher estradiol with telomere length are present. Further studies are needed to determine whether these hormonal exposures cooperate to slow biological aging.
\end{abstract}




\section{Introduction}

Reduced activity of the growth hormone (GH)-insulinlike growth factor 1 (IGF1) axis has been associated with extended lifespan in experimental models of invertebrates and mice $(1,2)$. IGF1 is a major downstream effector of $\mathrm{GH}$ that is present in relatively stable concentrations in the blood, providing an integrated measure of pulsatile $\mathrm{GH}$ secretion (3). IGF1 in the circulation binds to at least six IGF-binding proteins (IGFBPs). Of these two are of particular interest: IGFBP1 which is inversely associated with metabolic syndrome, and IGFBP3 which is the most abundant IGFbinding protein present in the circulation $(4,5)$.

In humans lower IGF1 concentrations have been associated with higher mortality due to ischemic heart disease (6). Consistent with this, higher serum IGF1 bioactivity has been associated with extended survival and reduced cardiovascular risk (7). However, there are contrasting results as low (8) and high (9) IGF1 concentrations have been associated with all-cause mortality. Similarly, contrasting results for IGFBP1 have been reported, with one study finding an association of low IGFBP1 with mortality from ischemic heart disease (6), and others associating higher IGFBP1 or increases in IGFBP1 with all-cause mortality $(10,11,12)$. Lower IGFBP3 concentrations were associated with increased mortality $(8,12)$. In addition to cardiovascular risk and longevity, the IGF1 axis has been associated with frailty in middle-aged and older men (13). The pathways by which different components of the IGF1 axis might influence a range of health outcomes during aging remain unclear.

Telomeres are essential DNA-protein complexes at the ends of chromosomes which protect them from fusion and degradation (14). Telomere shortening is associated with cellular senescence and is postulated to be both a contributory and interactive factor in diseases associated with ageing (14). Peripheral blood leucocyte telomere length (LTL) correlates with telomere length in vascular and other tissues $(15,16,17)$; thus, shorter LTL represents a biomarker for advanced biological age. Associations of IGF1 with LTL have been reported, but the nature of associations between IGFBP1 and IGFBP3 with LTL are unclear $(18,19,20)$. Furthermore, there is an interaction between the IGF1 axis and sex hormones, as estrogens mediate GH secretion in men (21). Higher estradiol concentrations are associated with longer LTL in men (22, 23), putatively via activation of the enzyme telomerase which lengthens telomeres $(24,25)$. However, studies examining whether the IGF1 axis and sex hormones might act together to influence telomere length are lacking.
The aim of this study was to clarify associations of plasma IGF1 and also IGFBP1 and IGFBP3 with LTL in a population-based cohort of older men, and to test the hypothesis that the IGF1 axis and sex hormones additively influence telomere length in men.

\section{Subjects and methods}

\section{Study population}

The Health In Men Study (HIMS) is a population-based cohort study of community-dwelling older men from Perth, Western Australia (26). In total, 12203 men aged $\geq 65$ years completed a questionnaire and attended for physical examination in Wave 1 (W1, 1996-1999). Subsequently, 4246 of these men then aged 70-89 years completed a second questionnaire, and attended for physical examination and venesection in Wave 2 (W2, 2001-2004). Men were predominantly of Caucasian ethnic origin. The University of Western Australia Human Research Ethics Committee approved the study, and all men gave written informed consent. After excluding 104 men taking androgen-related medications, 51 men with history of orchidectomy and then 559 men with history of prostate cancer, there were 3532 men in the dataset. We further excluded 128 men aged $85-89$ years as the number of men in this age stratum was small compared to other ages, and these men may have been healthy survivors less representative of older men as a whole. Some men had one or more missing data on IGF1, IGFBP1 or IGFBP3 $(n=188)$, LTL $(n=355)$ or other key covariates $(n=16)$ and were also excluded. After these exclusions there were 2999 community-dwelling men aged 70-84 years available for the analysis.

\section{Definition of medical comorbidities and physical activity levels}

Alcohol consumption and physical activity were determined by questionnaire at W1, and smoking status by questionnaire at W2. Physical activity was the sum of the number of hours in a usual week of non-vigorous and $2 \times$ the number of hours of vigorous physical activities, reflecting the higher exercise intensities associated with vigorous activities. Blood pressure, height and weight recorded at W2 were analysed. BMI was defined as weight ( $\mathrm{kg}$ ) divided by height (m) squared. A history of cardiovascular disease (CVD) was defined as any selfreported history of heart attack or stroke, heart bypass 
surgery or balloon angioplasty, aortic aneurysm, or surgery to the aorta, carotid or lower limb arteries at W2. Use of lipid-lowering and hypertensive medications was recorded from questionnaire responses at W2. Men diagnosed with diabetes, reporting use of glucose-lowering medication, or with fasting or non-fasting glucose at W2 of $\geq 7.0 \mathrm{mmol} / \mathrm{L}$ or $\geq 11.1 \mathrm{mmol} / \mathrm{L}$ respectively, were considered to have diabetes.

\section{Laboratory assays for circulating IGF1, IGFBP1, IGFBP3 and sex hormones}

Blood samples were collected between 08:00 and 10:30 $\mathrm{h}$ at W2. Plasma and serum aliquots were prepared immediately after phlebotomy and stored at $-80^{\circ} \mathrm{C}$ until assayed. Plasma total IGF1, IGFBP1 and IGFBP3 were assayed using reagent kits of single lot numbers from Diagnostics Systems Laboratories Inc. (DSL, supplied by Beckman Coulter) as previously described (4). The non-extraction IGF1 ELISA, the total IGFBP1 ELISA and the active IGFBP3 ELISA kits were used. The assays were automated using a Grifols Triturus ELISA processor (Vital Diagnostics, Castle Hill, NSW, Australia). Betweenrun imprecision (coefficient of variation) were IGF1: $12.2 \%$ at $117 \mu \mathrm{g} / \mathrm{L}$ and $8.6 \%$ at $216 \mu \mathrm{g} / \mathrm{L}$; IGFBP1: $8.6 \%$ at $3.1 \mu \mathrm{g} / \mathrm{L}$ and $5.2 \%$ at $49 \mu \mathrm{g} / \mathrm{L}$; IGFBP3: $16.8 \%$ at 540 $\mu \mathrm{g} / \mathrm{L}$ and $4.4 \%$ at $4300 \mu \mathrm{g} / \mathrm{L}$. Plasma total estradiol and testosterone concentrations were quantified using liquid chromatography-tandem mass spectrometry (LC-MS/MS) as previously described (27). Interassay coefficients of variation were estradiol: $8.6 \%$ at $103 \mathrm{pmol} / \mathrm{L}$ and $8.1 \%$ at $308 \mathrm{pmol} / \mathrm{L}$; testosterone: $6.5 \%$ at $2.0 \mathrm{nmol} / \mathrm{L}, 6.8 \%$ at 5.9 $\mathrm{nmol} / \mathrm{L}$, and $3.9 \%$ at $29.8 \mathrm{nmol} / \mathrm{L}$.

\section{Measurement of LTL}

From blood samples collected at W2 aliquots of leucocyte DNA were prepared and stored at $-80^{\circ} \mathrm{C}$ until required. An optimized PCR-based methodology for accurate measurement of LTL utilizing the protocol described by Cawthon et al. (28) was employed. Briefly, telomere lengths of the leucocyte DNA samples were measured by a multiplex quantitative PCR method (23). Each sample was amplified for telomeric DNA and for beta-globin, a singlecopy control gene, which was used as an internal control to normalize the starting amount of DNA. The K562 cell line was used as a standard (29). Periodic reproducibility experiments were performed to confirm adequate normalization. All samples, standards, and controls were run in triplicate, and the median value used for analyses.
A standard curve derived from K562 cell line was used to transform the cycle threshold into nanograms of DNA. The amount of telomeric DNA (T) was divided by the amount of single-copy control gene DNA (S), producing a relative measurement of the telomere length (T/S ratio). The coefficient of variation for the quantitative PCR across all batches was $<10 \%$. Some men did not provide a leucocyte DNA sample at W2 (choosing to provide blood samples only for plasma and serum); thus, LTL data were unavailable for them and they were excluded from the analysis.

\section{Statistical analysis}

SAS version 9.4 was used to analyze the data. Characteristics of the study sample are presented as mean \pm s.D. for continuous variables, and $n$ (\%) for categorical variables. The chi-square test was used to compare categorical variables and $t$-test for quantitative variables. In analyses of IGF1, IGFBP1 and IGFBP3 vs age and LTL vs age, data are expressed as mean and the s.E.M. Correlation coefficients and partial correlation coefficients were calculated for crude and age-adjusted associations of IGF1, IGFBP1 and IGFBP3 with T/S ratio, and for IGF variables with estradiol and testosterone. Linear regressions of $\mathrm{T} / \mathrm{S}$ ratio on each IGF variable separately were performed with adjustment for age and cardio-metabolic risk factors. The adjustment variables were age, BMI, CVD history, alcohol, smoking, physical activity, cholesterol, HDL, lipid medication, diabetes, systolic BP, hypertension medication and if the blood sample was taken fasting. Results are presented as the estimated coefficient ( $P$ value) where the coefficient represents the change in T/S ratio for a $1 \mathrm{SD}$ change in the IGF variable. To examine the joint associations of IGF variables and sex hormones on LTL, linear regressions of $\mathrm{T} / \mathrm{S}$ ratio on each IGF variable with either estradiol or testosterone included in the model were performed with adjustment for age and cardio-metabolic risk factors. In addition, we analyzed the differences in $\mathrm{T} / \mathrm{S}$ ratio according to low/high groups for IGF variables and sex hormones using median splits. Linear regression models were fitted that compared the mean $\mathrm{T} / \mathrm{S}$ ratio across the four groups (low IGF variable/low sex hormone (L/L), low IGF variable/high sex hormone (L/H), high IGF variable/ low sex hormone $(\mathrm{H} / \mathrm{L})$ and high IGF variable/high sex hormone $(\mathrm{H} / \mathrm{H}))$. Results are presented as the estimated (multivariable-adjusted) mean $\mathrm{T} / \mathrm{S}$ ratio for each of the four groups together with $P$ values for the comparison of each group to the low IGF variable/low sex hormone (L/L) group. A $P$ value $<0.05$ was considered significant. 


\section{Results}

\section{Characteristics of the study population}

Characteristics of the 2999 men comprising the final study sample and the 405 men excluded due to missing key data are shown in Table 1 . The excluded men drank on average slightly less alcohol, and fewer were current smokers, otherwise they had similar baseline characteristics and cardiovascular profiles to the study sample. Mean age of the 2999 men in the study sample was 76.7 years, $14.2 \%$ had a history of diabetes and $33.5 \%$ had CVD. In the study sample 2362 men (78.8\%) provided fasting blood samples, and fasting/non-fasting status was adjusted for in the analysis.

Table 1 Characteristics of the study sample aged 70-84 years ( $n=2999)$ and those excluded due to missing relevant data $(n=405)$. The table shows mean \pm S.D. or $n(\%)$. P values are from chi-square tests for categorical variables and from t-tests for quantitative variables.

\begin{tabular}{|c|c|c|c|}
\hline Characteristic & $\begin{array}{c}\text { Study sample } \\
\quad(n=2999)\end{array}$ & $\begin{array}{c}\text { Excluded } \\
\text { subjects }(n=405)\end{array}$ & $P$ value* \\
\hline Age (years) & $76.7 \pm 3.2$ & $77.0 \pm 3.3$ & 0.053 \\
\hline BMI $\left(\mathrm{kg} / \mathrm{m}^{2}\right)$ & $26.6 \pm 3.7$ & $26.3 \pm 3.3$ & 0.152 \\
\hline $\begin{array}{l}\text { Cardiovascular } \\
\text { disease history }\end{array}$ & $1006(33.5)$ & $123(30.4)$ & 0.203 \\
\hline Alcohol (g/day) & $12.0 \pm 15.6$ & $10.1 \pm 14.4$ & 0.020 \\
\hline \multicolumn{4}{|l|}{ Smoking } \\
\hline Never & $985(32.8)$ & $128(31.6)$ & 0.040 \\
\hline Former & $1830(61.0)$ & $264(65.2)$ & \\
\hline Current & $184(6.1)$ & $13(3.2)$ & \\
\hline $\begin{array}{l}\text { Physical activity } \\
\text { (h/week) }\end{array}$ & $7.00 \pm 7.14$ & $7.09 \pm 7.90$ & 0.814 \\
\hline $\begin{array}{r}\text { Cholesterol } \\
(\mathrm{mmol} / \mathrm{L})\end{array}$ & $4.89 \pm 0.95$ & $4.94 \pm 0.99$ & 0.288 \\
\hline $\mathrm{HDL}(\mathrm{mmol} / \mathrm{L})$ & $1.39 \pm 0.36$ & $1.41 \pm 0.34$ & 0.385 \\
\hline Lipids medication & $1182(39.4)$ & $134(33.1)$ & 0.014 \\
\hline Diabetes & $425(14.2)$ & 60 (14.9) & 0.699 \\
\hline $\begin{array}{l}\text { Systolic blood } \\
\text { pressure } \\
(\mathrm{mmHg})\end{array}$ & $147 \pm 20$ & $149 \pm 20$ & 0.155 \\
\hline $\begin{array}{r}\text { Hypertension } \\
\text { medication }\end{array}$ & $1656(55.2)$ & $206(50.9)$ & 0.098 \\
\hline $\begin{array}{l}\text { Fasting blood } \\
\text { sample }\end{array}$ & $2362(78.8)$ & $314(77.5)$ & 0.571 \\
\hline IGF1 ( $\mu \mathrm{g} / \mathrm{L})$ & $141.4 \pm 58.8$ & & \\
\hline IGFBP1 ( $\mu \mathrm{g} / \mathrm{L})$ & $26.6 \pm 20.5$ & & \\
\hline IGFBP3 $(\mu \mathrm{g} / \mathrm{L})$ & $3778 \pm 894$ & & \\
\hline Estradiol (pmol/L) & $73.1 \pm 29.0$ & & \\
\hline $\begin{array}{l}\text { Testosterone } \\
\text { (nmol/L) }\end{array}$ & $13.1 \pm 5.0$ & & \\
\hline LTL (T/S ratio) & $1.18 \pm 0.29$ & & \\
\hline
\end{tabular}

*Comparison of full study sample with excluded group for those with data on this variable.

\section{Associations of IGF1, IGFBP1, IGFBP3 and LTL with age}

The relationships of IGF variables and LTL with age are shown in Table 2. IGF1 declined by $18.4 \mu \mathrm{g} / \mathrm{L}$ per decade of age $(P<0.0001)$, IGFBP1 increased by $12.1 \mu \mathrm{g} / \mathrm{L}$ per decade of age $(P<0.0001)$ and IGFBP3 declined by $467 \mu \mathrm{g} / \mathrm{L}$ per decade of age $(P<0.0001)$. T/S ratio showed an overall estimated decline of 0.063 per decade of age $(P=0.0002)$.

\section{Correlations of IGF1, IGFBP1 and IGFBP3 with LTL}

The correlations and age-adjusted correlations between each IGF variable and LTL are shown in Table 3. IGF1 and IGFBP3 showed significant positive correlations and age-adjusted correlations with LTL. IGFBP1 was not significantly correlated with LTL. Correlations of estradiol but not testosterone with LTL were reported previously $(22,23)$.

\section{Associations of IGF variables with estradiol and testosterone}

Of the 2999 men in the study sample, 27 did not have recorded values for estradiol and testosterone, leaving 2972 men for further analysis. A matrix of age-adjusted correlations between IGF variables, estradiol and testosterone is shown in Table 4. Estradiol correlated with IGFBP1 $(r=0.09)$ and was inversely correlated with IGF1 $(r=-0.08)$ and IGFBP3 $(r=-0.10$, all $P<0.0001)$. Similar results were seen for testosterone.

\section{Regression analyses of IGF1, IGFBP1, IGFBP3 and LTL}

Linear regressions of $\mathrm{T} / \mathrm{S}$ ratio on IGF variables after adjustment for age, cardio-metabolic risk factors and CVD history are shown in Table 5. IGF1 and IGFBP3 (but not IGFBP1) showed a significant multivariable adjusted association with LTL. The estimated difference in T/S ratio was 0.015 per 1 s.D. increase in IGF1 $(P=0.007)$ and 0.011 per 1 s.D. increase in IGFBP3 $(P=0.049)$.

\section{Independent associations of IGF1 and IGFBP3, and estradiol, analyzed as continuous variables, with LTL}

Linear regressions of $\mathrm{T} / \mathrm{S}$ ratio on IGF variables in models also including either estradiol or testosterone, after adjustment for age, cardio-metabolic risk factors and 
Table 2 Relationships of IGF1, IGFBP1, IGFBP3 and leucocyte telomere length (LTL, expressed as the T/S ratio) with age in 2999 community-dwelling men aged $70-84$ years. Table shows mean \pm S.E.

\begin{tabular}{|c|c|c|}
\hline Age (years) & $n$ & IGFI $(\mu g / L)$ \\
\hline $70-74$ & 1162 & $148.8 \pm 1.77$ \\
\hline $75-79$ & 1330 & $138.7 \pm 1.60$ \\
\hline $80-84$ & 507 & $131.8 \pm 2.40$ \\
\hline All & 2999 & $141.4 \pm 1.07$ \\
\hline $\begin{array}{c}\text { Average change per } \\
\text { decade of age* }\end{array}$ & 2999 & $-18.4 \pm 3.34$ \\
\hline
\end{tabular}

\begin{tabular}{c}
\hline IGFBP1 $(\mu \mathrm{g} / \mathrm{L})$ \\
\hline $23.3 \pm 0.52$ \\
$27.5 \pm 0.58$ \\
$32.2 \pm 1.02$ \\
$26.6 \pm 0.37$ \\
$12.1 \pm 1.15$ \\
\hline
\end{tabular}

\begin{tabular}{c}
\hline IGFBP3 $(\mu \mathrm{g} / \mathrm{L})$ \\
\hline $3921 \pm 26.2$ \\
$3755 \pm 23.8$ \\
$3512 \pm 39.9$ \\
$3778 \pm 16.3$ \\
$-467 \pm 50.3$ \\
\hline
\end{tabular}

$\begin{array}{r}\hline \text { LTL }(T / S \text { ratio }) \\ \hline 1.20 \pm 0.009 \\ 1.17 \pm 0.008 \\ 1.14 \pm 0.012 \\ 1.18 \pm 0.005 \\ -0.063 \pm 0.017 \\ \hline\end{array}$

*Estimated from linear regression on age.

CVD history, are shown in Table 6. There was no evidence of any IGF*estradiol interaction when IGF1, IGFBP1, IGFBP3 and estradiol were modeled as continuous variables (all $P>0.05$, data not shown). IGF1 and estradiol were independently associated with longer telomeres, with an estimated increase in T/S ratio of 0.015 per 1 s.D. increase in IGF1 $(P=0.006)$ and 0.012 per 1 s.D. increase in estradiol $(P=0.027)$, when both estradiol and IGF1 were included in the same model (Table 6A). When IGFBP1 and estradiol were included in the same model, only estradiol was associated with LTL (Table 6B). IGFBP3 and estradiol were independently associated with longer telomeres, with an estimated increase in T/S ratio of 0.013 per 1 s.D. increase in IGFBP3 $(P=0.024)$ and 0.012 per 1 s.D. increase in estradiol $(P=0.026)$, when both estradiol and IGFBP3 were included in the same model (Table 6C). Testosterone was not associated with LTL in any of the models.

\section{Additive associations of IGF1 and estradiol, analyzed using median splits, with LTL}

Results using median splits are shown in Table 7. For IGF1/estradiol in the fully adjusted model, men in the $\mathrm{H} / \mathrm{H}$ group had the highest mean LTL, men in the $\mathrm{H} / \mathrm{L}$ and $\mathrm{L} / \mathrm{H}$ groups had intermediate LTL, and men in the $\mathrm{L} / \mathrm{L}$ group the shortest LTL. Only men in the $\mathrm{H} / \mathrm{H}$ group had significantly different mean LTL compared to L/L (mean T/S ratio 1.20 vs $1.16, P=0.018$ ) in the fully adjusted model. In the age-adjusted model for IGFBP3/estradiol, men in the $\mathrm{H} / \mathrm{H}$ group had the highest mean LTL (mean $\mathrm{T} / \mathrm{S}$ ratio 1.21 vs $1.17, P=0.030$ vs $\mathrm{L} / \mathrm{L}$ ), but this association was attenuated in the fully adjusted model ( $\mathrm{T} / \mathrm{S}$ ratio mean 1.20 vs $1.17, P=0.061)$. There was no difference between groups for IGFBP1/estradiol.

\section{Consideration of IGF1/IGFBP3 ratio}

The mean for IGF1/IGFBP3 ratio was 0.037 (s.D. 0.013). The age-adjusted correlation of IGF1/IGFBP3 with LTL
(T/S ratio) was $0.05(P=0.006)$ which was similar to the result for IGF1 (as shown in Table 3). The age-adjusted correlation between IGF1 and IGF1/IGFBP3 was very high at $0.78(P<0.0001)$; thus, results for IGF1/IGFBP3 ratio would be very similar to results for IGF1.

\section{Discussion}

In this study of community-dwelling older men, higher plasma IGF1 and IGFBP3 (but not IGFBP1) were associated with longer telomeres as assessed by LTL, independently of age and cardiometabolic risk factors. Furthermore, there were independent associations of circulating IGF1 and estradiol, and IGFBP3 and estradiol, with longer telomeres. Men with both plasma IGF1 and estradiol concentrations above the median value, had the longest telomeres, consistent with an additive association of these hormones with telomere length.

Previous studies assessing the relationship between IGF1 and LTL had not shown associations with IGFBPs and had not examined whether sex hormones and IGF1 might additively influence LTL $(18,19,20)$. MoverareSkrtic et al. studied 2744 men aged 69-81 years from the Osteoporotic Fractures in Men-Sweden study, finding that men with LTL in the lowest tertile had lower serum IGF1 compared to men in the two highest tertile groups (18). In a multivariable regression analysis a 1 s.D. higher IGF1 concentration was associated with 12\% lower risk

Table 3 Correlations and age-adjusted correlations of IGF1, IGFBP1 and IGFBP3 with leucocyte telomere length (LTL, T/S ratio) in 2999 men aged 70-84 years. Data are shown as correlation coefficient ( $P$ value).

\begin{tabular}{lccc}
\hline & $\begin{array}{c}\text { Correlation with } \\
\text { T/S ratio }(P \text { value })\end{array}$ & $\begin{array}{c}\text { Age-adjusted correlation } \\
\text { with T/S ratio }(P \text { value })\end{array}$ \\
\cline { 1 - 1 } IGF1 & $0.065(<0.001)$ & $0.059(0.001)$ \\
IGFBP1 & $-0.011(0.559)$ & $0.002(0.902)$ \\
IGFBP3 & $0.056(0.002)$ & $0.045(0.013)$ \\
\hline
\end{tabular}


Table 4 Correlations of IGF1, IGFBP1, IGFBP3, estradiol and testosterone in 2972 older men aged 70-84 years. Age-adjusted correlation coefficients and their corresponding P values (in brackets) are shown.

\begin{tabular}{|c|c|c|}
\hline & IGF1 & IGFBP1 \\
\hline $\begin{array}{l}\text { IGF1 } \\
\text { IGFBP1 } \\
\text { IGFBP3 } \\
\text { Estradiol } \\
\text { Testosterone }\end{array}$ & 1.000 & $\begin{array}{l}-0.142(<0.001) \\
1.000\end{array}$ \\
\hline
\end{tabular}

of having LTL in the lowest tertile of values, with no data shown for IGFBP1 or IGFBP3 (18). Kaplan et al. studied 551 adults aged $\geq 65$ years comprising 194 men and 357 women, and found that higher IGF1 was independently associated with longer LTL, but IGFBP1 and IGFBP3 were not (19). It is possible that their negative result with respect to IGFBP3, may relate to the smaller size of their study sample. Barbieri et al. reported an analysis of 476 adults aged 16-104 years with 208 men and 268 women, finding an age-adjusted association of IGF1 with LTL, and

Table 5 Multivariable linear regression showing associations of variables with LTL in 2999 community-dwelling men aged 70-84 years. Data shown are estimated coefficients ( $P$ values) where the coefficient represents the change in T/S ratio for a 1 S.D. change, or between categories, for each of the variables of interest.

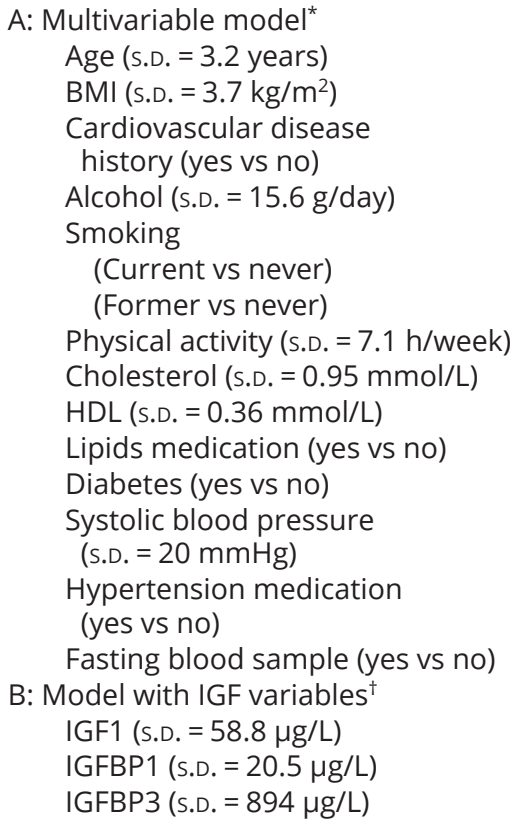

*Model includes all the variables shown. ${ }^{\dagger}$ Model includes age, BMI, CVD history, alcohol, smoking, physical activity, cholesterol, HDL, lipid medication, diabetes, systolic BP, hypertension medication and if the blood sample was taken fasting, and each of the IGF variables individually in three separate models (one shown in each row). no data shown for IGFBP1 or IGFBP3 (20). None of these studies examined sex hormones in conjunction with IGF1 and IGFBPs.

In our study, higher plasma IGF1 analyzed as a continuous variable was independently associated with longer LTL, with a substantive effect size. Thus a 1 s.D. increase in plasma IGF1 was associated with an increase in $\mathrm{T} / \mathrm{S}$ ratio of 0.015 , compared with estimated differences

Table 6 Multivariable linear regression showing associations of IGF variables and sex hormones with LTL in 2972 community-dwelling men aged $70-84$ years. Data shown are estimated coefficients ( $P$ values) where the coefficient represents the change in T/S ratio for a 1 S.D. change, for each of the variables of interest.

\begin{tabular}{|c|c|}
\hline & Coefficient ( $P$ value) \\
\hline \multicolumn{2}{|l|}{ A: Model with IGF1 and estradiol* } \\
\hline IGF1 (s.D. = $58.8 \mu \mathrm{g} / \mathrm{L}$ ) & $0.0149(0.006)$ \\
\hline Estradiol (s.D. $=29.0 \mathrm{pmol} / \mathrm{L}$ ) & $0.0121(0.027)$ \\
\hline \multicolumn{2}{|l|}{ Model with IGF1 and testosterone* } \\
\hline IGF1 & $0.0138(0.012)$ \\
\hline Testosterone (s.D. = $5.0 \mathrm{nmol} / \mathrm{L}$ ) & $-0.0015(0.801)$ \\
\hline \multicolumn{2}{|l|}{ B: Model with IGFBP1 and estradiolt } \\
\hline IGFBP1 (s.D. = $20.5 \mu \mathrm{g} / \mathrm{L})$ & $-0.0001(0.981)$ \\
\hline Estradiol & $0.0110(0.045)$ \\
\hline \multicolumn{2}{|l|}{$\begin{array}{l}\text { Model with IGFBP1 and } \\
\text { testosterone }^{\dagger}\end{array}$} \\
\hline IGFBP1 & $0.0011(0.856)$ \\
\hline Testosterone & $-0.0033(0.579)$ \\
\hline \multicolumn{2}{|l|}{ C: Model with IGFBP3 and estradiol } \\
\hline IGFBP3 (S.D. = $894 \mu \mathrm{g} / \mathrm{L})$ & $0.0127(0.024)$ \\
\hline Estradiol & $0.0123(0.026)$ \\
\hline \multicolumn{2}{|l|}{$\begin{array}{l}\text { Model with IGFBP3 and } \\
\text { testosterone }\end{array}$} \\
\hline IGFBP3 & $0.0113(0.048)$ \\
\hline Testosterone & $-0.0013(0.828)$ \\
\hline
\end{tabular}

*Model includes age, BMI, CVD history, alcohol, smoking, physical activity, cholesterol, HDL, lipid medication, diabetes, systolic BP, hypertension medication and if the blood sample was taken fasting, and IGF1 and sex hormone in the same model. tModel includes age, BMI, CVD history, alcohol, smoking, physical activity, cholesterol, HDL, lipid medication, diabetes, systolic BP, hypertension medication and if the blood sample was taken fasting, and IGFBP1 and sex hormone in the same model. ¥Model includes age, BMI, CVD history, alcohol, smoking, physical activity, cholesterol, HDL, lipid medication, diabetes, systolic BP, hypertension medication and if the blood sample was taken fasting, and IGFBP3 and sex hormone in the same model. 
Table 7 T/S ratio in older men according to concentrations of IGF variables and estradiol stratified using median splits. ${ }^{*}$ Data are shown as adjusted mean ( $\mathrm{P}$ value) from linear regression for T/S ratio according to IGF variable/estradiol groups.

\begin{tabular}{|c|c|c|c|c|}
\hline IGF variable (median) & $\begin{array}{c}\text { Low IGF and low } \\
\text { estradiol }\end{array}$ & $\begin{array}{c}\text { Low IGF and high } \\
\text { estradiol }^{\dagger}\end{array}$ & $\begin{array}{l}\text { High IGF and low } \\
\text { estradiol }^{\dagger}\end{array}$ & $\begin{array}{l}\text { High IGF and high } \\
\text { estradiol }^{\dagger}\end{array}$ \\
\hline \multicolumn{5}{|l|}{ Group sizes } \\
\hline IGF1 & 729 & 755 & 755 & 733 \\
\hline IGFBP1 & 796 & 693 & 688 & 795 \\
\hline IGFBP3 & 714 & 769 & 770 & 719 \\
\hline \multicolumn{5}{|c|}{ Age-adjusted T/S ratio means } \\
\hline IGF1 (133) & 1.16 & $1.16(0.877)$ & $1.18(0.147)$ & $1.20(0.007)$ \\
\hline IGFBP1 (21.7) & 1.18 & $1.18(0.623)$ & $1.17(0.786)$ & $1.18(0.545)$ \\
\hline IGFBP3 (3770) & 1.17 & $1.16(0.629)$ & $1.18(0.779)$ & $1.21(0.030)$ \\
\hline \multicolumn{5}{|c|}{ Multivariable-adjusted T/S ratio means $\mathrm{s}^{\ddagger}$} \\
\hline IGF1 (133) & 1.16 & $1.17(0.870)$ & $1.18(0.257)$ & $1.20(0.018)$ \\
\hline IGFBP1 (21.7) & 1.18 & $1.18(0.674)$ & $1.17(0.713)$ & $1.18(0.584)$ \\
\hline IGFBP3 (3770) & 1.17 & $1.17(0.646)$ & $1.17(0.983)$ & $1.20(0.061)$ \\
\hline
\end{tabular}

*Estradiol median is $70 \mathrm{pmol} / \mathrm{L}$. Medians for IGF variables are shown in brackets in the table in units of $\mu \mathrm{g} / \mathrm{L}$. $† P$ value for comparison with low IGF variable and low estradiol group. ¥Adjusted for age, BMI, CVD history, alcohol, smoking, physical activity, cholesterol, high-density lipoprotein cholesterol $(\mathrm{HDL})$, lipid medication, diabetes, systolic BP, hypertension medication and if the blood sample was taken fasting.

of 0.021 for being 3.2 years (1 s.D.) younger, and 0.013 for having a BMI $3.7 \mathrm{~kg} / \mathrm{m}^{2}$ (1 S.D.) lower. These results are supportive of the concept that IGF1 might favorably influence ageing trajectories. Higher IGF1 concentrations have been associated with lower risk of mortality in some epidemiological studies $(7,8)$, but other such studies have reported neutral $(10,11)$ or even adverse associations of IGF1 with mortality (9). IGF1 has multiple biological actions including modulation of cell growth and proliferation, including in the vasculature (30). Thus, the association of higher IGF1 with longer telomeres, a marker for younger biological age, is consistent with findings from studies which have associated lower IGF1 concentrations with cardiovascular risk factors such as hypertension and diabetes (31), presence of arterial plaque (32), deaths from ischemic heart disease (6) and worsening frailty phenotype (13). Contrary to studies in laboratory animals which associate reduced activity of the GH/IGF1 axis with longevity $(1,2)$ or studies in patients with acromegaly who have pathologically excessive GH secretion and shorter telomeres (33), our results are consistent with higher IGF1 concentrations within the physiological range being associated with slower biological aging in older men.

We found that higher IGFBP3 concentrations were independently associated with longer LTL, with a 1 s.D. increase in IGFBP3 associated with an increase in T/S ratio of 0.011, approximately half the difference seen with a 1 s.D. change in age. IGF1 and IGFBP3 concentrations are correlated, and in some studies the associations of lower IGFBP3 with specific outcomes in men mirror the associations of lower IGF1, for example with metabolic syndrome (4), all-cause mortality (8) and worsening frailty (13). However, analyses of other outcomes show divergent associations, for example, in the HIMS cohort men with higher plasma IGFBP3 had a lower incidence of dementia, while plasma IGF1 was not a predictor of dementia risk (34). In another analysis, higher IGFBP3 (but not IGF1) was associated with colorectal cancer risk (35). IGFBP3 has been shown to bind endothelial cells (36), be actively internalized via an endocytic pathway (37), and is involved in regulation of apoptosis (38) and adipocyte differentiation via nuclear localization (39). Therefore, while it is possible that the association of higher IGFBP3 with longer LTL reflects the parallel association of IGF1 with this endpoint, an alternative explanation might be that IGFBP3 may modulate LTL via mechanisms distinct from IGF1. Notably, all trans retinoic acid and activated retinoid $\mathrm{X}$ receptor $\alpha(\mathrm{RXR} \alpha)$ have recently been found to regulate LTL (40) as have polymorphic variants of PPAR gamma (41); that IGFBP3 heterodimerizes with RXR $\alpha$ (42) and interacts with PPAR gamma (39), could link IGFBP3 activity to LTL through nuclear receptor binding and regulation, independent of IGF1.

In our study there was no association of IGFBP1 with LTL. There is a strong inverse association of IGFBP1 with risk of metabolic syndrome (4). In one study lower IGFBP1 concentrations were associated with higher ischemic heart disease but not all-cause mortality (6), in other studies higher IGFBP1 concentrations were associated with greater all-cause mortality $(10,12)$. Therefore the overall impact of IGFBP1 on aging remains to be elucidated, and it does not appear to be associated with LTL.

Testosterone stimulates GH secretion in hypogonadal men via aromatization to estradiol (43), and blockade 
of aromatase with letrozole reduces circulating estradiol and peak GH response to arginine in men (21). However, while administration of GH increases circulating IGF1 in healthy men, there was no additive effect of GH combined with testosterone in this setting (44). We found that estradiol and testosterone were inversely associated with both IGF1 and IGFBP3, after adjusting for age. However, estradiol and IGF1 concentrations were independently and positively associated with LTL, as were estradiol and IGFBP3. A 1 s.D. increase in plasma estradiol was associated with an increase in $\mathrm{T} / \mathrm{S}$ ratio of 0.012 , similar in magnitude to that seen with a 1 s.D. increase in IGF1, when both were included in the same regression model. A similar result was seen with estradiol and IGFBP3. Men with both estradiol and IGF1 concentrations above the median value, had longer telomeres compared to men with both of estradiol and IGF1 below the median. The difference between groups (mean T/S ratio 1.20 vs 1.16 in multivariable-adjusted model) is comparable to the difference seen between 5-year age strata (e.g. mean T/S ratio in men $70-74$ years 1.20 vs men $75-79$ years 1.17 ). Therefore, our results are consistent with independent and additive associations of higher estradiol and higher IGF1 with LTL in older men.

Of note, GH treatment increases, and GH receptor blockade decreases, both IGF1 and estradiol concentrations (45). GH increases the estradiol/testosterone ratio, consistent with an effect on aromatase activity (45), while IGF1 enhances aromatase activity in vitro (46). However, we found an inverse association of estradiol with IGF1, which makes it less likely that high concentrations of IGF1 might have contributed to increased conversion of testosterone to estradiol in our study cohort.

We previously reported associations of higher estradiol with longer telomere length in younger, middle-aged and older men $(22,23)$. The underlying mechanism may relate to increased expression and activity of telomerase, the enzyme which lengthens telomeres by synthesis of new telomeric repeats (TTAGGG)n, as shown in cell line and animal models $(14,24,25,47)$. Of note, IGF1 has been shown to reduce telomere length in fibroblasts (33) but enhances the effect of phytohaemagglutinin to increase telomerase activity in cord blood mononuclear cells (48), suggesting that IGF1 exerts effects on telomere length in vitro which may be cell-type specific. Other studies, albeit in prostate cancer cells, have reported that IGF1 induced telomerase activity, mediated via the phosphoinositol 3-kinase-Akt kinase pathway, and increased mRNA expression and protein levels of the catalytic reverse transcriptase subunit of telomerase, hTERT (49). While other studies have shown in prostate cancer cells that IGFBP2 stimulates telomerase activity (50), when tested no effect of IGFBP3 was observed in vitro (49). The novel observation of additive associations of higher estradiol and higher IGF1 with LTL may be due to contributory actions of each hormone on telomerase activity and regulation of telomere length. However, it is also possible that higher IGF1 may reflect higher protein intake which may favor longevity in older, but not younger, adults (51). Therefore an alternative explanation for our findings is that they reflect a direct contribution of higher estradiol to telomerase activity, and an indirect contribution of higher IGF1 as a marker for biological factors relevant to aging in older men.

Other studies have linked the IGF1 axis to longevity in a contrasting manner, noting that centenarians and their offspring have lower IGF1 concentrations and IGF1 bioactivity compared to controls matched to the offspring $(52,53)$. In the Leiden Longevity Study, nonagenarians with IGF1/IGFBP3 ratios in the lowest quartile had greater longevity and better functional status compared with those in the highest quartile (54). It is possible that those findings reflect a selected population of the very oldest survivors or contrasting influences of the IGF1 axis on different aspects of ageing. Further work is needed to clarify the role of both sex hormones and the IGF1 axis to influence biological ageing in relation to nutritional status, health and longevity (55).

Limitations of this study are the single measurement of plasma IGF1, IGFBP1 and IGFBP3 and LTL at one timepoint. We did not have serial blood samples for repeated measurements of these variables. As this is a cross-sectional analysis, causation cannot be inferred therefore it is not possible to establish a clear cause-and-effect relationship between variables. We measured total IGF1 and did not measure either free IGF1 or IGF1 bioactivity (7), nor did we measure circulating IGFBP1 phosphorylation status which may affect IGF1 bioactivity (56). Nevertheless, assays of total IGF1, IGFBP1 and IGFBP3 at a single timepoint have been informative in other studies $(4,6,8,9$, $10,12)$. As blood samples were collected from surviving men at Wave 2, it is possible that these men as a group might have had higher IGF1 concentrations and longer telomeres than may have been the case had sampling been undertaken at Wave 1 and involved men who subsequently died prior to Wave 2 . However, this should not have affected our results as associations between IGF1 and LTL were analysed as continuous variables and using median splits, rather than relying on absolute threshold values. 
Another limitation of the study was that of 4246 men included at Wave 2, only 2999 were available for the analysis. However, the major reasons for exclusion were medications or comorbidities likely to affect sex hormone status which could confound the analysis, and missing relevant data. As the missing relevant data were largely accounted for by men who did not provide DNA samples for assay of LTL, there is no reason to suspect this could have biased the findings. Nevertheless, the possibility of bias cannot be dismissed. The HIMS cohort comprises men who had previously attended an earlier wave of the study, who returned for re-assessment and blood sampling. Therefore, our results may be more applicable to generally healthier older men. Associations between the IGF1 axis, sex hormones and LTL may be different in populations of younger or middle-aged men. The HIMS population is predominantly of Caucasian ethnicity, so additional studies would be needed to confirm our findings in men from other ethnic groups, and we cannot extrapolate our results to women.

Strengths of the study are the large cohort of community-dwelling older men, in whom not only IGF1 but also IGFBP1 and IGFBP3, and also estradiol and testosterone results were available. Sex hormones were assayed using LC-MS/MS. We assayed LTL using a method that correlates with the gold standard of Southern blot (28), which is feasible and practical for epidemiological studies. The cohort of men aged 70-84 years identifies an important and expanding demographic vulnerable to ill health. The multivariable models included age, BMI, smoking, alcohol, physical activity, and history of diabetes and cardiovascular disease, making it less likely that the results were confounded by age, underlying illhealth or physical factors.

In conclusion, higher IGF1 and IGFBP3 in the physiological range are independently associated with longer telomeres, consistent with lower biological age, in older men. Additive influences of higher IGF1 and higher estradiol on telomere length are present, suggesting that the IGF1 axis and sex hormones jointly influence telomere length in vivo. Further work is needed to clarify the mechanisms underlying these associations, and thus, to explore whether hormonal exposures might cooperatively modulate biological ageing.

\section{Declaration of interest}

$\mathrm{KKYH}$ is on the editorial board of EJE. K KY H was not involved in the review or editorial process for this paper, on which he/she is listed as an author. The other authors have nothing to disclose.

\section{Funding}

The work was funded by National Health and Medical Council of Australia (NHMRC) Project Grants 513823, 1060557 and 1121548. J G holds a NHMRC Practitioner Fellowship 1117061 and a Senior Clinical Research Fellowship from the Queensland Government, Australia.

\section{Acknowledgements}

The authors thank Surya Sutanto, University of Sydney, and the staff of PathWest Laboratory Medicine, Fiona Stanley and Fremantle Hospitals, and the ANZAC Research Institute, for their excellent technical assistance. They especially thank all the men and staff who participated in the Health In Men Study.

\section{References}

1 Brown-Borg HM, Borg KE, Meliska CJ \& Bartke A. Dwarf mice and the ageing process. Nature 1996384 33. (https://doi. org/10.1038/384033a0)

2 Tatar M, Bartke A \& Antebi A. The endocrine regulation of aging by insulin-like signals. Science 2003299 1346-1351. (https://doi. org/10.1126/science.1081447)

3 Chanson P, Arnoux A, Mavromati M, Brailly-Tabard S, Massart C, Young J, Piketty ML, Souberbielle JC \& VARIETE Investigators. Reference values for IGF-I serum concentrations: comparison of six immunoassays. Journal of Clinical Endocrinology and Metabolism 2016 101 3450-3458. (https://doi.org/10.1210/jc.2016-1257)

4 Yeap BB, Chubb SAP, Ho KKY, Setoh JWS, McCaul KA, Norman PE, Jamrozik K \& Flicker L. IGF1 and its binding proteins 3 and 1 are differentially associated with metabolic syndrome in older men. European Journal of Endocrinology 2010162 249-257. (https://doi. org/10.1530/EJE-09-0852)

5 Ranke MB. Insulin-like growth factor binding-protein-3 (IGFBP-3). Best Practice and Research: Clinical Endocrinology and Metabolism 2015 29 701-711. (https://doi.org/10.1016/j.beem.2015.06.003)

6 Laughlin GA, Barrett-Connor E, Criqui MH \& Kritz-Silverstein D. The prospective association of serum insulin-like growth factor I (IGF-I) and IGF-binding protein-1 levels with all cause and cardiovascular disease mortality in older adults: the Rancho Bernardo Study. Journal of Clinical Endocrinology and Metabolism 200489 114-120. (https:// doi.org/10.1210/jc.2003-030967)

7 Brugts MP, van den Beld AW, Hofland LJ, van der Wansem K, van Koetsveld PM, Frystyk J, Lamberts SWJ \& Janssen JA. Low circulating insulin-like growth factor I bioactivity in elderly men is associated with increased mortality. Journal of Clinical Endocrinology and Metabolism 200893 2515-2522. (https://doi.org/10.1210/jc.20071633)

8 Friedrich N, Haring R, Nauck M, Ludemann J, Rosskopf D, SpilckeLiss E, Felix SB, Dorr M, Brabant G, Volzke H et al. Mortality and serum insulin-like growth factor (IGF)-I and IGF binding protein 3 concentrations. Journal of Clinical Endocrinology and Metabolism 2009 94 1732-1739. (https://doi.org/10.1210/jc.2008-2138)

9 Andreassen M, Raymond I, Kistrop C, Hildebrandt P, Faber J \& Kristensen LØ. IGF1 as a predictor of all cause mortality and cardiovascular disease in an elderly population. European Journal of Endocrinology 2009160 25-31. (https://doi.org/10.1530/EJE-08-0452)

$10 \mathrm{Hu}$ D, Pawlikowska L, Kanaya A, Hsueh WC, Colbert L, Newman AB, Satterfield S, Rosen C, Cummings SR, Harris TB et al. Serum insulinlike growth factor- 1 binding proteins 1 and 2 and mortality in older adults: the Health, Aging, and Body Composition Study. Journal of the American Geriatrics Society 200957 1213-1218. (https://doi. org/10.1111/j.1532-5415.2009.02318.x) 
11 Kaplan RC, Buzkova P, Cappola AR, Strickler HD, McGinn AP, Mercer LD, Arnold AM, Pollak MN \& Newman AB. Decline in circulating insulin-like growth factors and mortality in older adults: Cardiovascular Health Study All-Stars Study. Journal of Clinical Endocrinology and Metabolism 201297 1970-1976. (https://doi. org/10.1210/jc.2011-2967)

12 Yeap BB, Chubb SAP, McCaul KA, Ho KKY, Hankey GJ, Norman PE \& Flicker L. Associations of IGF1 and IGFBPs 1 and 3 with all-cause and cardiovascular mortality in older men: the Health in Men Study. European Journal of Endocrinology 2011164 715-723. (https://doi. org/10.1530/EJE-11-0059)

13 Swiecicka A, Lunt M, Ahern T, O’Neill TW, Bartfai G, Casanueva FF, Forti G, Giwercman A, Han TS, Lean MEJ et al. Nonandrogenic anabolic hormones predict risk of frailty: European Male Ageing Study Prospective Data. Journal of Clinical Endocrinology and Metabolism 2017102 2798-2806. (https://doi.org/10.1210/jc.201700090)

14 Blackburn EH, Epel ES \& Lin J. Human telomere biology: a contributory and interactive factor in aging, disease risks, and protection. Science 2015350 1193-1198. (https://doi.org/10.1126/ science.aab3389)

15 Friedrich U, Griese E-U, Schwab M, Fritz P, Thon K-P \& Klotz U. Telomere length in different tissues of elderly patients. Mechanisms of Ageing and Development 2000119 89-99. (https://doi.org/10.1016/ s0047-6374(00)00173-1)

16 Wilson WRW, Herbert KE, Mistry Y, Stevens SE, Patel HR, Hastings RA, Thompson MM \& Williams B. Blood leucocyte telomere DNA content predicts vascular telomere DNA content in humans with and without vascular disease. European Heart Journal 200829 2689-2694. (https://doi.org/10.1093/eurheartj/ehn386)

17 Daniali L, Benetos A, Susser E, Kark JD, Labat C, Kimura M, Desai KK, Granick M \& Aviv A. Telomeres shorten at equivalent rates in somatic tissues of adults. Nature Communications $2013 \mathbf{4} 1597$. (https://doi.org/10.1038/ncomms2602)

18 Moverare-Skrtic S, Svensson J, Karlsson MK, Orwoll E, Ljunggren O, Mellstrom D \& Ohlsson C. Serum insulin-like growth factor-I concentration is associated with leukocyte telomere length in a population-based cohort of elderly men. Journal of Clinical Endocrinology and Metabolism 200994 5078-5084. (https://doi. org/10.1210/jc.2009-1450)

19 Kaplan RC, Fitzpatrick AL, Pollak MN, Gardner JP, Jenny NS, McGinn AP, Kuller LH, Strickler HD, Kimura M, Psaty BM et al. Insulin-like growth factors and leukocyte telomere length: the Cardiovascular Health Study. Journals of Gerontology 200964 1103-1106. (https://doi.org/10.1093/gerona/glp036)

20 Barbieri M, Paolisso G, Kimura M, Gardner JP, Boccardi V, Papa M, Hjelmborg JV, Christensen K, Brimacombe M, Nawrot TS et al. Higher circulating levels of IGF-I are associated with longer leukocyte telomere length in healthy subjects. Mechanisms of Ageing and Development 2009130 771-776. (https://doi.org/10.1016/j. $\operatorname{mad} .2009 .10 .002)$

21 Birzniece V, McLean M, Reddy N \& Ho KKY. Disparate effect of aromatization on the central regulation of $\mathrm{GH}$ secretion by estrogens in men and postmenopausal women. Journal of Clinical Endocrinology and Metabolism 2019104 2978-2984. (https://doi.org/10.1210/ jc.2019-00265)

22 Yeap BB, Knuiman MW, Divitini ML, Hui J, Arscott GM, Handelsman DJ, McLennan SV, Twigg SM, McQuillan B, Hung J et al. Epidemiological and Mendelian randomisation studies of dihydrotestosterone and estradiol, and leucocyte telomere length in men. Journal of Clinical Endocrinology and Metabolism 2016101 1299-1306. (https://doi.org/10.1210/jc.2015-4139)

23 Yeap BB, Hui J, Knuiman MW, Handelsman DJ, Flicker L, Divitini ML, Arscott GM, McLennan SV, Twigg SM, Almeida OP et al. Cross-sectional associations of sex hormones with leucocyte telomere length, a marker of biological age, in a community-based cohort of older men. Clinical Endocrinology 201990 562-569. (https://doi. org/10.1111/cen.13918)

24 Calado RT, Yewdell WT, Wilkerson KL, Regal JA, Kajigaya S, Stratakis CA \& Young NS. Sex hormones, acting on the tert gene, increase telomerase activity in human primary hematopoietic cells. Blood 2009114 2236-2243. (https://doi.org/10.1182/blood-2008-09178871)

25 Sato R, Maesawa C, Fujisawa K, Wada K, Oikawa K, Takikawa Y, Suzuki K, Oikawa H, Ishikawa K \& Masuda T. Prevention of critical telomere shortening by oestradiol in human normal hepatic cultured cells and carbon tetrachloride induced rat liver fibrosis. Gut 200453 1001-1009. (https://doi.org/10.1136/gut.2003.027516)

26 Norman PE, Flicker L, Almeida OP, Hankey GJ, Hyde Z \& Jamrozik K. Cohort profile: the Health in Men Study (HIMS). International Journal of Epidemiology 200938 48-52. (https://doi.org/10.1093/ije/dyn041)

27 Yeap BB, Alfonso H, Chubb SAP, Handelsman DJ, Hankey GJ, Norman PE \& Flicker L. Reference ranges and determinants of testosterone, dihydrotestosterone and estradiol levels measured using liquid chromatography-tandem mass spectrometry in a populationbased cohort of older men. Journal of Clinical Endocrinology and Metabolism 201297 4030-4039. (https://doi.org/10.1210/jc.20122265)

28 Cawthon RM. Telomere length measurement by a novel monochrome multiplex quantitative PCR method. Nucleic Acids Research 200937 e21. (https://doi.org/10.1093/nar/gkn1027)

29 Codd V, Mangino M, van der Harst P, Braund PS, Kaiser M, Beveridge AJ, Rafelt S, Moore J, Nelson C, Soranzo N et al. Common variants near TERC are associated with mean telomere length. Nature Genetics 201042 197-199. (https://doi.org/10.1038/ng.532)

30 Higashi Y, Gautam S, Delafontaine P \& Sukhanov S. IGF-I and cardiovascular disease. Growth Hormone and IGF Research 201945 6-16. (https://doi.org/10.1016/j.ghir.2019.01.002)

31 Colao A, Di Somma C, Cascella T, Pivonello R, Vitale G, Grasso LFS, Lombardi G \& Savastano S. Relationships between serum IGF1 levels, blood pressure, and glucose tolerance: an observational, exploratory study in 404 subjects. European Journal of Endocrinology 2008159 389-397. (https://doi.org/10.1530/EJE-08-0201)

32 Martin RM, Gunnell D, Whitley E, Nicolaides A, Griffin M, Georgiou N, Smith GD, Ebrahim S \& Holy JMP. Associations of insulinlike growth factor (IGF)-I, IGF-II, IGF binding protein (IGFBP)-2 and IGFBP-3 with ultrasound measures of atherosclerosis and plaque stability in an older population. Journal of Clinical Endocrinology and Metabolism 200893 1331-1338. (https://doi: 10.1210/jc.2007-2295)

33 Matsumoto R, Fukuoka H, Iguchi G, Odake Y, Yoshida K, Bando H, Suda K, Nishizawa H, Takahashi M, Yamada S et al. Accelerated telomere shorteing in acromegaly: IGF-I induces telomere shortening and cellular senescence. PLOS ONE 201510 e0140189. (https://doi. org/10.1371/journal.pone.0140189)

34 Almeida OP, Hankey GJ, Yeap BB, Chubb SAP, Golledge J \& Flicker L. Risk of prevalent and incident dementia associated with insulinlike growth factor and insulin-like growth factor-binding protein 3 . Molecular Psychiatry 201823 1825-1829. (https://doi.org/10.1038/ mp.2017.152)

35 Chan YX, Alfonso H, Paul Chubb SA, Ho KKY, Gerard Fegan P, Hankey GJ, Golledge J, Flicker L \& Yeap BB. Higher IGFBP3 is associated with increased incidence of colorectal cancer in older men independently of IGF1. Clinical Endocrinology 201888 333-340. (https://doi.org/10.1111/cen.13499)

36 Booth BA, Boes M, Dake BL, Knudtson KL \& Bar RS. IGFBP-3 binding to endothelial cells inhibits plasmin and thrombin proteolysis. American Journal of Physiology: Endocrinology and Metabolism 2002282 E52-E58. (https://doi.org/10.1152/ajpendo.2002.282.1.E52)

37 Lee KW, Liu B, Ma L, Li H, Bang P, Koeffler HP \& Cohen P. Cellular internalisation of insulin-like growth factor binding protein-3. Journal of Biological Chemistry 2004279 469-476. (https://doi. org/10.1074/jbc.M307316200) 
38 Lee KW, Ma L, Yan X, Liu B, Zhang XK \& Cohen P. Rapid apoptosis induction by IGFBP-3 involves an insulin-like growth factorindependent nucleomitochondrial translocation of RXR $\alpha / \mathrm{Nur} 77$. Journal of Biological Chemistry 2005280 16942-16948. (https://doi. org/10.1074/jbc.M412757200)

39 Chan SSY, Schedlich LJ, Twigg SM \& Baxter RC. Inhibition of adipocyte differentiation by insulin-like growth factor-binding protein-3. American Journal of Physiology: Endocrinology and Metabolism 2009296 E654-E663. (https://doi.org/10.1152/ajpendo.90846.2008)

40 Eitsuka T, Nakagawa K, Kato S, Ito J, Otoki Y, Takasu S, Shimuzu N, Takahashi T \& Miyazawa T. Modulation of telomerase activity in cancer cells by dietary compounds: a review. International Journal of Molecular Sciences 201819 478. (https://doi.org/10.3390/ ijms19020478)

41 Garcia-Calzon S, Martinez-Gonzalez MA, Razquin C, Corella D, SalasSalvado J, Martinez JA, Zalba G \& Marti A. Pro12Ala polymorphism of the PPAR 2 gene interacts with a Mediterranean diet to prevent telomere shortening in the PREDIMED-Navarra randomized trial. Circulation: Cardiovascular Genetics 20158 91-99. (https://doi. org/10.1161/CIRCGENETICS.114.000635)

42 Baxter RC. Insulin-like growth factor binding protein-3 (IGFBP3): novel ligands mediate unexpected functions. Journal of Cell Communication and Signaling 20137 179-189. (https://doi. org/10.1007/s12079-013-0203-9)

43 Weissberger AJ \& Ho KK. Activation of the somatotropic axis by testosterone in adult males: evidence for the role of aromatization. Journal of Clinical Endocrinology and Metabolism 199376 1407-1412. (https://doi.org/10.1210/jcem.76.6.8501143)

44 Munzer T, Rosen CJ, Harman SM, Pabst KM, St Clair C, Sorkin JD \& Blackman MR. Effects of GH and/or sex steroids on circulating IGF-I and IGFBPs in healthy, aged women and men. American Journal of Physiology: Endocrinology and Metabolism 2006290 E1006-E1013. (https://doi.org/10.1152/ajpendo.00166.2005)

45 Andreassen M, Frystyk J, Faber J, Kristensen LØ \& Juul A. Growth hormone $(\mathrm{GH})$ activity is associated with increased serum oestradiol and reduced anti-Mullerian hormone in healthy male volunteers treated with Gh and a GH antagonist. Andrology 20131 595-601. (https://doi.org/10.1111/j.2047-2927.2013.00096.x)

46 Zhang B, Shozu M, Okada M, Ishikawa H, Kasai T, Murakami K, Nomura K, Harada N \& Inoue M. Insulin-like growth factor I enhances the expression of aromatase $\mathrm{P} 450$ by inhibiting autophagy. Endocrinology 2010151 4949-4958. (https://doi.org/10.1210/ en.2010-0294)

47 Bayne S, Li H, Jones MEE, Pinto AR, van Sinderen M, Drummond A, Simpson ER \& Liu JP. Estrogen deficiency reversibly induces telomere shortening in mouse granulosa cells and ovarian ageing in vivo. Protein and Cell 20112 333-346. (https://doi.org/10.1007/s13238011-1033-2)

48 Ti W, Zhang DK, Cheung PT, Tsao SW \& Lau YL. Effect of insulin-like growth factor 1 on PHA-stimulated cord blood mononuclear cell telomerase activity. British Journal of Haematology 1999104 785-794. (https://doi.org/10.1046/j.1365-2141.1999.01272.x)

49 Wetterau LA, Francis MJ, Ma L \& Cohen P. Insulin-like growth factor I stimulates telomerase activity in prostate cancer cells. Journal of Clinical Endocrinology and Metabolism 200388 3354-3359. (https:// doi.org/10.1210/jc.2002-021326)

50 Moore MG, Wetterau LA, Francis MJ, Peehl DM \& Cohen P. Novel stimulatory role for insulin-like growth factor binding protein-2 in prostate cancer cells. International Journal of Cancer 2003 105 14-19. (https://doi.org/10.1002/ijc.11015)

51 Levine ME, Suarez JA, Brandhorst S, Balasubramanian P, Cheng CW, Madia F, Fontana L, Mirisola MG, Guevara-Aguirre J, Wan J et al. Low protein intake is associated with a major reduction in IGF1 , cancer, and overall mortality in the 65 and younger but not older population. Cell Metabolism 201419 407-417. (https://doi. org/10.1016/j.cmet.2014.02.006)

52 Vitale G, Brugts MP, Ogliari G, Castaldi D, Fatti LM, Varewijck AJ, Lamberts SW, Monti D, Bucci L, Cevenini E et al. Low circulating IGF-I bioactivity is associated with human longevity. Findings in centenarians' offspring. Aging 20124 580-589. (https://doi. org/10.18632/aging.100484)

53 Vitale G, Barbieri M, Kamenetskaya M \& Paolisso G. GH/IGF-I/ insulin system in centenarians. Mechanisms of Ageing and Development 2017165 107-114. (https://doi.org/10.1016/j.mad.2016.12.001)

54 Van der Spoel E, Rozing MP, Houwing-Duistermaat JJ, Slagboom PE, Beekman M, de Craen AJM, Westendorp RGJ \& van Heemst D. Association analysis of insulin-like growth factor-1 axis parameters with survival and functional status in nonagenarians of the Leiden Longevity Study. Aging 20157 956-963. (https://doi.org/10.18632/ aging.100841)

55 Vitale G, Pellegrino G, Vollery M \& Hofland LJ. Role of the IGF-1 system in the modulation of longevity: controversies and new insights from a centenarians' perspective. Frontiers in Endocrinology 201910 27. (https://doi.org/10.3389/fendo.2019.00027)

56 Borai A, Livingstone C, Ghayour-Mobarhan M, Abousa A, Shafi S, Mehta S, Heidari A, Emadzadeh A, Wark G \& Ferns G. Serum insulinlike growth factor binding protein-1 (IGFBP-1) phosphorylation status in subjects with and without ischaemic heart disease. Atherosclerosis 2010208 593-598. (https://doi.org/10.1016/j. atherosclerosis.2009.08.010)

Received 13 August 2019

Revised version received 21 October 2019

Accepted 28 October 2019 